\title{
DAMPAK KINERJA LINGKUNGAN, KEPEMILIKAN INSTITUSIONAL, KEPEMILIKAN PUBLIK, LEVERAGE, UKURAN PERUSAHAAN DAN PERTUMBUHAN PERUSAHAAN TERHADAP PENGUNGKAPAN TANGGUNGJAWAB SOSIAL
}

\author{
Erva Wartyna \\ Prima Apriwenni* \\ Program Studi Akuntansi, Institut Bisnis dan Informatika Kwik Kian Gie, \\ Jl. Yos Sudarso Kav. 87, Jakarta 14350
}

\begin{abstract}
The company's obligation is not only to seek profit but also to do social responsibility (CSR). For companies that use natural resources in operational activities, it is appropriate to conduct CSR activities and disclose them in annual reports. This study aims to determine whether environmental performance, institutional and public share ownership, leverage, size and growth of the company affect the disclosure of CSR. Sample of the research is 25 agricultural and mining companies listed in Indonesia Stock Exchange (IDX) over a period of 4 years (2013-2016). While the analysis to be used are equality coefficient test, classical assumption test, multiple linear regression analysis, and statistic test.The results of this study concluded there is sufficient evidence on the variables of environmental performance and firm size affecting CSR disclosure, whereas in institutional ownership variables, public ownership, leverage, and corporate growth there is not enough evidence of these variables affecting CSR disclosure.
\end{abstract}

Keyword: CSR Disclosure, Institutional Ownership, Public Ownership, Leverage, Size Firm

\begin{abstract}
Abstrak
Kewajiban perseroan bukan hanya mencari laba semata namun harus melakukan tanggung jawab sosial (CSR). Bagi perusahaan yang menggunakan sumber daya alam dalam kegiatan operasional, sudah sepatutnya melakukan kegiatan CSR dan mengungkapkannya di dalam laporan tahunan. Penelitian ini bertujuan untuk mengetahui apakah kinerja lingkungan, kepemilikan institusi, kepemilikan publik, leverage, ukuran serta pertumbuhan perusahaan berpengaruh terhadap pengungkapan CSR. Sampel penelitian adalah 25 perusahaan pertanian dan pertambangan yang terdaftar di BEI selama periode 4 tahun (2013-2016). Teknik analisis data yang digunakan adalah analisis deskriptif, uji kesamaan koefisien, uji asumsi klasik, analisis regresi linier berganda, dan uji statistik. Hasil penelitian ini menyimpulkan terdapat cukup bukti bahwa variabel kinerja lingkungan dan ukuran perusahaan mempengaruhi pengungkapan CSR, sedangkan variabelvariabel kepemilikan institusional, kepemilikan publik, leverage, dan pertumbuhan perusahaan tidak terdapat cukup bukti bahwa variabel-variabel tersebut mempengaruhi pengungkapan CSR.
\end{abstract}

Kata kunci: Pengungkapan CSR, Kepemilikan Institusi, Kepemilikan Publik, Leverage, Ukuran Perusahaan

\footnotetext{
* Alamat kini:Institut Bisnis dan Informatika Kwik Kian Gie, Jln Yos Sudarso Kav. 87 Sunter , Jakarta 14350 Penulis untuk Korespondensi: Telp. (021) 65307062 Ext. 708. E-mail: prima.apriwenni@kwikkiangie.ac.id
} 


\section{Pendahuluan}

$\mathrm{L}$

aporan keuangan diartikan sebagai dokumen Perkembangan dunia bisnis yang semakin luas saat ini menimbulkan persaingan yang semakin ketat antar perusahaan. Mereka pun saling berlomba menciptakan produk beraneka ragam yang mampu memenuhi kebutuhan dan kepuasan para konsumen demi mampu bersaing di pasar bisnis. Selain itu, perusahaan juga harus menciptakan dan mempertahankan citra perusahaan yang baik di mata para konsumennya untuk menjamin pertumbuhan perusahaan secara berkelanjutan (sustainability).

Pada dasarnya setiap perusahaan yang didirikan bertujuan untuk mendapatkan laba. Namun, saat ini informasi keuangan saja tidak cukup untuk menjamin keberlanjutan perusahaan. Hal tersebut didukung oleh Kamil dan Herusetya (2012) yang menyatakan bahwa perusahaan menganggap bahwa tanggung jawab sosial sangat penting untuk mengangkat citra perusahaan. Oleh karena itu berapapun laba yang diperoleh oleh entitas tidak akan menurunkan atau meningkatkan tanggung jawab sosial yang dilakukan entitas.

Setiap entitas dalam menjalankan kegiatan usahanya tentu tidak terlepas dari pengaruh masyarakat dan lingkungan sekitarnya, sehingga menciptakan hubungan timbal balik antara masyarakat dan perusahaan. Perusahaan membutuhkan suatu respon yang positif dari masyarakat yang dapat diperoleh melalui apa yang dilakukan oleh perusahaan kepada para stakeholders, termasuk masyarakat dan lingkungan sekitar (Kamil dan Herusetya, 2012). Hal tersebut dapat diwujudkan melalui tanggung jawab sosial perusahaan (CSR).

CSR merupakan suatu tindakan atau konsep yang dilakukan oleh perusahaan sebagai bentuk tanggung jawab mereka terhadap sosial atau lingkungan sekitar dimana perusahaan itu berada (Fauzan, 2011).
Program CSR merupakan salah satu program sosial yang dihadirkan perusahaan dalam rangka membangun citra yang baik pada masyarakat luas melalui kegiatan sosial yang diadakan perusahaan untuk kepentingan masyarakat di segala bidang yang dibutuhkan.

Pelaksanaan CSR di Indonesia didukung oleh Undang-Undang Republik Indonesia Nomor 40 Tahun 2007 Pasal 74 ayat 1 tentang Perseroan Terbatas yang menyatakan bahwa suatu perseroan yang menjalankan kegiatan usahanya di bidang dan/atau yang berkaitan dengan sumber daya alam wajib melaksanakan Tanggung Jawab Sosial dan Lingkungan. Kewajiban perseroan untuk melaksanakan tanggung jawab sosial dan lingkungan ini akan dianggarkan dan diperhitungkan sebagai biaya perseroan dengan memperhatikan kepatutan dan kewajaran. Sedangkan bagi perseroan yang tidak melaksanakan kewajiban tersebut akan dikenakan sanksi sesuai dengan peraturan perundang-undangan.

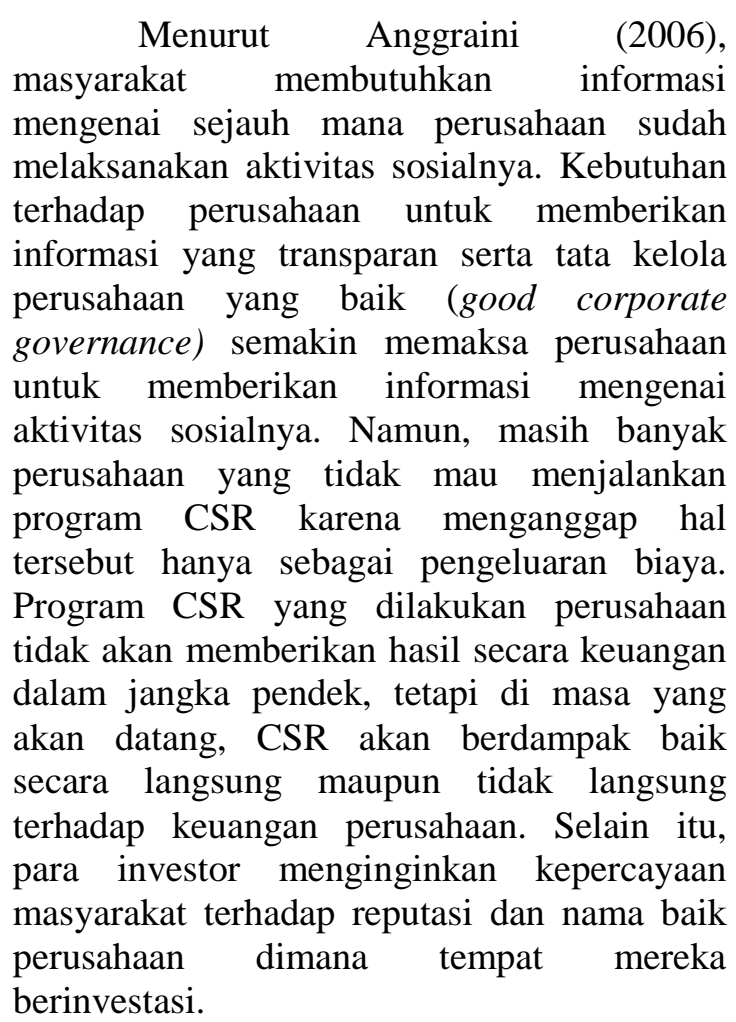
perusahaan
berinvestasi. 
Banyaknya dampak negatif yang ditimbulkan oleh perusahaan terhadap lingkungan dan masyarakat, sehingga banyak peneliti yang membuat kajian mengenai Corporate Social Responsibility (CSR). Luasnya pengungkapan tanggung jawab sosial ditentukan oleh sejumlah faktor, salah satunya adalah kinerja lingkungan. Pemerintah melalui Kementerian Lingkungan Hidup membentuk Program Penilaian Peringkat Kinerja Perusahaan dalam Pengelolaan Lingkungan Hidup (PROPER) yang telah dilaksanakan mulai tahun 2002 di bidang pengendalian dampak lingkungan untuk meningkatkan peran perusahaan dalam program pelestarian lingkungan hidup. Hal ini dilakukan untuk menilai kinerja lingkungan perusahaan dan memacu agar perusahaan semakin baik dalam usaha untuk memperhatikan lingkungan sekitar.

Kinerja lingkungan perusahaan diukur dengan menggunakan warna mulai dari yang terbaik emas, hijau, biru, merah hingga yang terburuk, yaitu hitam. Melalui ini, masyarakat akan lebih mudah mengetahui tingkat penataan pengelolaan pada perusahaan dengan hanya melihat warna yang ada (Rakhiemah dan Agustia, 2009). Penelitian yang dilakukan oleh Permana dan Raharja (2012) menyatakan bahwa kinerja lingkungan berpengaruh terhadap pengungkapan CSR. Hal ini berbanding terbalik dengan penelitian Oktalia (2014) yang menemukan bahwa kinerja lingkungan yang diukur dengan peringkat PROPER tidak berpengaruh signifikan terhadap pengungkapan CSR.

Selain kinerja lingkungan, variabel yang akan diteliti dalam penelitian ini adalah karakteristik perusahaan yang terdiri dari kepemilikan institusi, kepemilikan publik, leverage, size dan growth.

Rumusan masalah yang akan dibahas dalam penelitian ini adalah apakah kinerja lingkungan, kepemilikan institusional, kepemilikan publik, leverage, ukuran perusahaan, dan pertumbuhan perusahaan berpengaruh terhadap pengungkapan tanggung jawab sosial perusahaan pada perusahaan pertanian dan pertambangan yang terdaftar di BEI periode 2013-2016.

Tujuan penelitian ini adalah untuk mengetahui apakah kinerja lingkungan, kepemilikan institusional, kepemilikan publik, leverage, ukuran perusahaan, dan pertumbuhan perusahaan mempengaruhi pengungkapan tanggung jawab sosial perusahaan pada perusahaan pertanian dan pertambangan yang terdaftar di BEI periode 2013-2016.

\section{Teori Agensi}

Menurut (Jensen \& Meckling, 1976) hubungan keagenan adalah sebagai kontrak, dimana satu atau beberapa orang (principal) mempekerjakan orang lain (agent) untuk melaksanakan sejumlah jasa dan mendelegasikan wewenang untuk mengambil keputusan kepada agen tersebut. Teori agensi menganalisis dan mencari solusi atas dua permasalahan yang muncul dalam hubungan antara para pemegang saham sebagai "principal" dan manajer suatu perusahaan sebagai "agent".

\section{Teori Stakeholder}

Teori stakeholder merupakan suatu gagasan bahwa perusahaan bukanlah entitas yang hanya beroperasi untuk kepentingan perusahaan itu sendiri namun harus mampu memberikan manfaat bagi para stakeholder. Dengan demikian, kelangsungan hidup suatu perusahaan sangat dipengaruhi oleh dukungan yang diberikan oleh stakeholder perusahaan tersebut (Ghozali \& Chariri, 2007).

\section{Teori Legitimasi}

Legitimasi merupakan keadaan psikologis keberpihakan suatu individu dan kelompok yang sangat peka terhadap gejala lingkungan sekitarnya baik fisik maupun nonfisik (Hadi, 2011). Menurut Suchman 
(1995) legitimasi dianggap sebagai persepsi umum bahwa tindakan yang dilakukan suatu entitas merupakan tindakan yang diinginkan, pantas atau sesuai dengan sistem, norma, nilai, kepercayaan dan definisi yang dikembangkan secara sosial. Teori legitimasi menyatakan bahwa organisasi harus secara terus menerus mencoba untuk meyakinkan bahwa mereka melakukan kegiatan sesuai dengan batasan dan norma-norma masyarakat.

\section{Pengungkapan CSR}

Pengungkapan tanggung jawab sosial perusahaan merupakan proses komunikasi publik perusahaan atas peran mereka dalam mengelola lingkungan, sosial dan ekonomi masyarakat berkaitan dengan bisnis inti perusahaan (Sukanto \& Widaryanti, 2014).

Pengungkapan CSR perusahaan dapat digambarkan sebagai ketersediaan informasi keuangan dan non-keuangan yang meliputi manfaat sosial dan biaya sosial berkaitan dengan interaksi organisasi dengan lingkungannya. Penyediaan informasi yang luas dalam laporan keuangan merupakan keharusan yang disebabkan adanya permintaan berbagai pihak yang berkepentingan dengan informasi tersebut.

\section{Kinerja Lingkungan}

Kinerja lingkungan merupakan
kinerja perusahaan dalam lingkungan dan mewujudkan keselarasan dan keseimbangan antara manusia dan lingkungan hidup serta terkendalinya pemanfaatan sumber daya secara bijaksana (Rochayatun, 2016). Untuk mengukur kinerja lingkungan perusahaan, Kementrian Lingkungan Hidup (KLH) menggunakan peringkat yang dilakukan dala PROPER. PROPER merupakan instrumen untuk mengukur tingkat ketaatan perusahaan berdasarkan peraturan yang berlaku (Rakhiemah dan Agustia, 2009:4). PROPER diumumkan secara annual kepada masyarakat, sehingga perusahaan yang dinilai akan memperoleh imbal balik atas reputasinya yang bersifat negatif atau positif, tergantung kepada tingkat ketaatannya.

Menurut Oktalia (2014), kinerja lingkungan dipengaruhi oleh sejauh mana tindakan proaktif terhadap pengelolaan lingkungan yang dilakukan oleh berbagai organisasi atau perusahaan. Semakin besar peran perusahaan dalam kegiatan lingkungannya, maka semakin banyak pula informasi mengenai kinerja lingkungan yang harus diungkapkan oleh manajemen dalam laporan tahunan. Hal tersebut dapat menjadi langkah untuk mewujudkan transparansi dari perusahaan serta dapat menunjukkan bahwa perusahaan bertanggung jawab atas dampak yang ditimbulkan terhadap masyarakat dan lingkungan sekitar. Masyarakat juga dapat mengetahui seberapa besar andil perusahaan terhadap kelestarian lingkungan dan kesejahteraan masyarakat sekitarnya.

$\mathrm{Ha}_{1}$ : Kinerja lingkungan berpengaruh positif terhadap pengungkapan $C S R$.

\section{Kepemilikan Institusional}

Kepemilikan institusional adalah kepemilikan saham perusahaan oleh institusi atau badan usaha. Pemegang saham institusional juga memiliki opportunity, resources, dan expertise untuk menganalisis kinerja dan tindakan manajemen. Investor institusional umumnya merupakan pemegang saham yang cukup besar karena memiliki pendanaan yang besar. Semakin besar kepemilikan institusional, maka semakin besar tekanan terhadap manajemen untuk mengungkapkan tanggung jawab sosial perusahaan. Tingkat kepemilikan institusional yang tinggi menimbulkan usaha pengawasan yang lebih besar untuk memonitor kinerja manajemen sehingga dapat menghalangi perilaku opportunistic manajer.

Struktur kepemilikan institusional yang besar akan sangat berpengaruh pada keputusan manajemen yang akan diambil. Salah satu keputusannya adalah pengungkapan informasi tanggung jawab 
sosial perusahaan. Penelitian yang dilakukan oleh Karima (2014) menunjukkan bahwa kepemilikan institusional berpengaruh signifikan terhadap pengungkapan CSR pada perusahaan go public yang terdaftar di BEI tahun 2009-2011. Hasil tersebut bertentangan dengan penelitian (Bangun, Octavia, \& Tarigan, 2012) yang menemukan bahwa kepemilikan institusional tidak memiliki pengaruh yang signifikan terhadap pengungkapan CSR.

$\mathrm{Ha}_{2}$ : Kepemilikan institusional berpengaruh positif terhadap pengungkapan $C S R$.

\section{Kepemilikan Publik}

Perusahaan go-public dan telah terdaftar di BEI adalah perusahaan-perusahaan yang memiliki proporsi kepemilikan saham oleh publik. Hal itu berarti semua aktivitas dan keadaan perusahaan harus dilaporkan dan diketahui oleh publik sebagai salah satu bagian pemegang saham. Kepemilikan saham oleh publik yang dimaksud adalah jumlah saham yang dimiliki oleh publik. Pengertian publik yang dimaksud adalah pihak individu di luar manajemen dan tidak memiliki hubungan istimewa dengan perusahaan.

Masyarakat selaku salah satu investor bagi perusahaan memiliki kekuatan dan pengalaman untuk melindungi hak dan kepentingan seluruh pemegang saham, sehingga mereka akan menuntut perusahaan untuk melakukan komunikasi dan mengungkapkan seluruh informasi mengenai aktivitas secara transparan.

Semakin banyak saham yang dimiliki oleh publik maka semakin tinggi pengawasan yang dilakukan oleh publik terhadap seluruh kegiatan yang dilakukan oleh perusahaan. Hal itu dapat mendorong perusahaan untuk melakukan kegiatan yang dapat menarik para investor dan mendapat legitimasi atau kepercayaan dari masyarakat. Salah satunya dengan melaksanakan kegiatan CSR. Hal tersebut menunjukkan bahwa kepemilikan saham publik yang relatif besar akan mendorong meningkatnya pengungkapan informasi aktivitas tanggung jawab sosial (CSR) yang dilakukan oleh perusahaan.

Sejalan dengan hasil penelitian Rahayu (2015) bahwa kepemilikan saham publik berpengaruh positif terhadap pengungkapan tanggung jawab sosial. Namun berbeda dengan Evandini \& Darsono (2014:8) yang melakukan penelitian mengenai kepemilikan saham publik menyatakan hasil penelitiannya bahwa perusahaan dengan adanya kepemilikan saham publik tidak mengungkapkan CSR yang lebih luas yang berarti kepemilikan saham publik tidak berpengaruh terhadap pengungkapan CSR.

$\mathrm{Ha}_{3}$ : Kepemilikan saham publik berpengaruh positif terhadap pengungkapan $C S R$.

\section{Leverage}

Leverage adalah penggunaan aset dan sumber dana (source of funds) oleh perusahaan yang memiliki biaya tetap (beban tetap) dengan maksud agar meningkatkan keuntungan potensial pemegang saham (Sartono, 2008). Leverage menjelaskan seberapa besar rasio antara total kewajiban dengan total modal perusahaan.

Leverage merupakan alat untuk mengukur seberapa besar rasio antara total kewajiban dengan total modal perusahaan.Semakin tinggi rasio leverage maka semakin besar pula kewajiban perusahaan untuk memenuhi kebutuhan informasi kreditur jangka panjang. Salah satu caranya adalah dengan menyediakan informasi secara lebih lengkap untuk menghilangkan keraguan pemegang obligasi terhadap dipenuhinya hak-hak mereka. Pentingnya tambahan informasi khususnya pengungkapan mengenai kegiatan tanggung jawab sosial (CSR) yang menunjukkan bahwa entitas memiliki peluang untuk tetap bertahan (going concern).

Penelitian mengenai pengaruh leverage terhadap pengungkapan CSR 
dilakukan oleh Evandini \& Darsono (2014) yang menemukan bahwa leverage memiliki pengaruh yang signifikan terhadap luas pengungkapan sosial dalam laporan tahunan perusahaan. Perusahaan yang memiliki leverage yang lebih besar akan cenderung memberikan pengungkapan sosial yang lebih luas. Hasil yang berbeda ditunjukkan oleh penelitian Paramitha (2016) bahwa leverage tidak berpengaruh terhadap pengungkapan CSR.

$\mathrm{Ha}_{4}$ : Leverage berpengaruh positif terhadap pengungkapan $C S R$.

\section{Ukuran Perusahaan}

Ukuran perusahaan merupakan variabel yang banyak digunakan untuk menjelaskan variasi pengungkapan dalam laporan tahunan perusahaan. Hal tersebut berkaitan dengan teori legitimasi bahwa perusahaan dengan ukuran yang lebih besar melakukan aktivitas operasional yang lebih banyak sehingga memiliki pengaruh yang lebih besar terhadap masyarakat.

Perusahaan dengan ukuran yang lebih besar akan melakukan aktivitas operasional lebih banyak sehingga memiliki pengaruh yang lebih besar terhadap masyarakat. Oleh karena itu, semakin besarnya ukuran suatu perusahaan maka semakin besar pula kemampuan perusahaan dalam melakukan pengungkapan tanggung jawab sosialnya dimana suatu aktivitas CSR cenderung membutuhkan biaya yang cukup besar. Pengeluaran biaya tersebut akan berdampak kepada kebijakan manajemen dalam mengungkapkan informasi secara luas mengenai aspek sosial dan lingkungan.

Pandangan ini sejalan dengan hasil penelitian yang dilakukan oleh Purwanto (2011) serta Evandini dan Darsono (2014) yang menunjukkan bahwa ukuran perusahaan berpengaruh signifikan terhadap pengungkapan CSR. Namun, dalam penelitian Oktariani dan Mimba (2014) menunjukkan hasil yang berbeda dimana size tidak berpengaruh signifikan terhadap pengungkapan CSR.

$\mathrm{Ha}_{5}$ : Ukuran perusahaan berpengaruh positif terhadap pengungkapan $C S R$.

\section{Pertumbuhan Perusahaan}

Pertumbuhan perusahaan (growth) merupakan salah satu pertimbangan para investor dalam menanamkan investasinya. dimana pertumbuhan dapat menunjukan peningkatan kinerja keuangan perusahaan yang diharapkan oleh para stakeholders akan memberikan laba yang tinggi atau laba yang persisten di masa depan. Perusahaan yang memiliki tingkat pertumbuhan (growth) yang tinggi menjadi sebuah sinyal yang baik bagi stakeholder sehingga akan lebih mudah untuk menarik modal dari para investor. Apabila perusahaan terus bertumbuh maka akan menarik respon positif dari investor lebih besar. Rasio pertumbuhan perusahaan menunjukan seberapa baik kinerja perusahaan dalam kegiatan perekonomian.

Pertumbuhan perusahaan (Growth) diukur dengan pertumbuhan penjualan perusahaan yang mencerminkan manifestasi keberhasilan investasi periode masa lalu dan dapat dijadikan prediksi pertumbuhan masa yang akan datang. Pertumbuhan penjualan juga merupakan indikator permintaan dan daya saing perusahaan dalam suatu industri. Menurut Lomboan, dkk. (2016) laju pertumbuhan suatu perusahaan akan mempengaruhi kemampuan mempertahankan keuntungan dalam mendanai kesempatankesempatan pada masa yang akan datang.

Perusahaan dengan tingkat pertumbuhan yang tinggi akan lebih disorot oleh publik sehingga cenderung lebih banyak mengungkapkan informasi tanggung jawab sosialnya $(C S R)$. Hal itu disebabkan oleh informasi tanggung jawab sosial akan membuat perusahaan tersebut memperoleh respon positif dari publik dan para stakeholders yang akan memicu pertumbuhan perusahaan. Jika suatu perusahaan memiliki 
pertumbuhan yang baik maka perusahaan akan terlihat lebih unggul dan mampu menghadapi persaingan di masa depan. Menurut hasil penelitian yang dilakukan oleh Munsaidah, Andini, dan Supriyanto (2016:10) menunjukan bahwa pertumbuhan perusahaan berpengaruh positif terhadap CSR. Sedangkan penelitian dilakukan oleh Lomboan, dkk (2016 menyatakan bahwa pertumbuhan perusahaan mempunyai tidak berpengaruh signifikan terhadap pengungkapan tanggung jawab sosial perusahaan.

$\mathrm{Ha}_{6}$ : Pertumbuhan perusahaan berpengaruh positif terhadap pengungkapan $C S R$.

\section{Metode Penelitian}

Penelitian ini menggunakan data dari laporan keuangan dan laporan tahunanpada tahun 2013-2016 pada perusahaan pertanian dan pertambangan yang terdaftar di Bursa Efek Indonesia (BEI). Penelitian ini menggunakan sampel sebanyak 25 perusahaan pertanian dan pertambangan yang terdaftar di Bursa Efek Indonesia selama 4 tahun periode pengamatan, sehingga total sampel menjadi 100 perusahaan denganmempertimbangkan kelengkapan dan data laporan tahunan masing-masing emiten.

\section{Definisi Operasional Variabel dan Pengukuran Variabel Penelitian}

\section{Variabel Dependen}

Variabel dependen dalam penelitian ini adalah pengungkapan tanggung jawab sosial perusahaan. Pengungkapan Corporate Social Responsibility (CSRD) diukur dengan menggunakan indikator dari Global Reporting Income (GRI) dengan jumlah 91 item pengungkapan. Setiap item tanggung jawab sosial dalam instrument penelitian diberi nilai satu (1) jika diungkapkan dan nilai nol (0) jika tidak diungkapkan. Penelitian ini dibatasi subjektivitas peneliti dalam memberi skor.

Pengungkapan CSR diukur menggunakan rasio yang diperoleh melalui rumus:

\section{CSRD $=\frac{\text { JumlahItemCSRDyangdiungkapkan }}{\text { Y1 itemCSRDmenurutGKI G4 }}$}

\section{Variabel Independen}

\section{a. Kinerja Lingkungan}

Kinerja Lingkungan diukur berdasarkan pada peringkat kinerja yang diperoleh perusahaan dalam PROPER. Sistem peringkat kinerja PROPER mencakup pemeringkatan perusahaan dalam lima warna yang akan diberikan skor 5: emas, skor 4: hijau, skor 3: biru, skor 2: merah, skor 1: hitam, skor 0: tidak mengikuti PROPER.

\section{b. Kepemilikan Institusi}

Kepemilikan institusional (INST) diukur dengan persentase kepemilikan saham oleh pihak investor institusional. Besar persentase kepemilikan institusional dapat dilihat dalam laporan tahunan perusahaan: Rasio kepemilikan institusional dapat dihitung dengan rumus:

INS $=\frac{\text { Jumlah Kepemilikan Institusional }}{\text { Total Lanbar Saham Yerusahaan }} \times 100 \%$

\section{c. Kepemilikan Saham Publik}

Kepemilikan Saham Publik (KP) dapat dilihat dalam laporan tahunan perusahaan. Besarnya saham publik atau masyarakat diukur melalui rasio dari jumlah kepemilikan lembar saham yang dimiliki publik terhadap total saham perusahaan di Indonesia. Rasio kepemilikan saham publik diukur dengan rumus sebagai berikut:

$\mathbf{K P}=\frac{\text { JumlahKepemilitan Saham Publik }}{\text { Total Lembar Saham Yerusahaan }} \times 100 \%$

\section{d. Leverage}

Leverage dapat diartikan sebagai tingkat ketergantungan perusahaan terhadap hutang dalam membiayai kegiatan operasinya, dengan demikian leverage juga mencerminkan tingkat resiko keuangan perusahaan, Leverage diukur dengan total 
kewajiban dibagi dengan ekuitas pemegang saham.

$$
\text { DER }=\frac{\text { Iotal Kewgiban }}{\text { Elutas }}
$$

\section{e. Ukuran Perusahaan}

Ukuran perusahaan adalah besarnya lingkup atau luas perusahaan dalam menjalankan operasinya. Sebagai proksi ukuran perusahaan, penelitian ini menggunakan log of total assets yaitu logaritma natural jumlah aktiva yang dimiliki perusahaan.

SIZE $=\log$ (nilai total aktiva)

\section{f. Pertumbuhan Perusahaan}

Pertumbuhan perusahaan dalam penelitian ini diukur dengan pertumbuhan penjualan perusahaan. Rumus yang digunakan untuk mengukur pertumbuhan perusahaan yaitu:

$$
\text { GROWTH }=\frac{\text { Penjuaian }- \text { Perjualan }_{\mathrm{E}} \text { ] }}{\text { Penfualan }_{\mathrm{i}-1}}
$$

Keterangan:

$\mathrm{t}=$ penjualan tahun saat ini

$\mathrm{t}_{-1}=$ Penjualan tahun sebelumnya

\section{Teknik Pengambilan Sampel}

Dalam penelitian ini terdapat 100 sampel terdiri dari 25 perusahaan yang dapat dilihat pada tabel 1. Sampel diambil dengan menggunakan metode purposive sampling. Berdasarkan seleksi yang telah dilakukan, berikut ini kriteria yang digunakan untuk menyeleksi sampel penelitian:

1. Sampel penelitian merupakan perusahaan yang terdaftar di BEI sampai dengan 31 Desember 2013 dan tidak delisting.

2. Sampel penelitian harus menyajikan laporan tahunan secara lengkap sampai dengan tahun 2016.

3. Sampel penelitian harus menyajikan pengungkapan tanggung jawab sosial dalam laporan tahunannya.
4. Sampel penelitian menyajikan laporan keuangan dalam mata uang Rupiah.

\section{Teknik Analisis Data}

1. Membuat Daftar Checklist Pengungkapan Sosial

Checklist disusun dalam bentuk daftar tema pengungkapan, yang merupakan daftar tema yang terdapat pada indeks GRI-G4 yaitu ekonomi, lingkungan, dan sosial yang terdiri dari 91 item.

2. Analisis Statistik Deskriptif

Analisis statistik deskriptif digunakan untuk memberikan gambaran atau deskripsi suatu data yang dilihat dari nilai rata-rata (mean), standar deviasi, nilai maksimum, nilai minimum, dan lainlain (Ghozali, 2016).

3. Uji Kesamaan Koefisien (Pooling)

Langkah selanjutnya yang dilakukan dalam penelitian ini adalah melakukan uji pooling yang berarti penggabungan data cross sectional dan time series dengan cara membuat variabel dummy untuk tiap tahunnya, lalu dikalikan ke tiap-tiap variabel independen. Kriteria keputusan dalam uji kesamaan koefisien:

a. Bila nilai sig. $\leq 0.05$ maka terdapat perbedaan koefisien dan tidak dapat dilakukan pooling. Maka pengujian data penelitian harus dilakukan pertahun.

b. Bila nilai sig. $>0.05$ maka tidak terdapat perbedaan koefisien dan dapat dilakukan pooling. Maka pengujian data penelitian dapat dilakukan selama periode penelitian dalam 1 kali uji.

4. Uji Asumsi Klasik

a. Uji Normalitas

Uji normalitas bertujuan untuk menguji apakah dalam model regresi, variabel pengganggu atau residual memiliki distribusi normal (Ghozali, 2016: 154),. Model regresi 
yang baik adalah yang mempunyai distribusi data normal atau mendekati normal. Alat uji yang digunakan oleh peneliti adalah metode KolmogorovSmirnov Z (1-Sample K-S). Dasar pengambilan keputusan uji statistik tersebut adalah:

1) Jika nilai Asymp. Sig. (2-tailed) kurang dari 0,05 , maka $\mathrm{H}_{0}$ ditolak. Hal ini berarti data residual terdistribusi tidak normal.

2) Jika nilai Asymp. Sig. (2-tailed) lebih dari 0,05 , maka $\mathrm{H}_{0}$ diterima. Hal ini berarti data residual terdistribusi normal.

b. Uji Multikolinearitas

Uji multikolinearitas bertujuan untuk menguji apakah dalam model regresi ditemukan adanya korelasi antar variabel bebas/independen (Ghozali, 2016:103). Model regresi yang baik seharusnya tidak terjadi korelasi diantara variabel independen. Untuk mendeteksi ada atau tidaknya multikolinearitas, dapat dilihat dari nilai tolerance dan variance. Nilai cut-off yang umum adalah :

1) Nilai Tolerance $>0.1$ dan nilai VIF $<10$, maka tidak ada multikolinearitas antara variabel independen dalam model regresi.

2) Nilai Tolerance $<0.1$ dan nilai $\mathrm{VIF}>10$, maka ada multikolinearitas antara variabel independen dalam modelregresi.

c. Uji Heteroskedastisitas

Uji heteroskedastisitas bertujuan menguji apakah dalam model regresi terjadi ketidaksamaan variance dari residual satu pengamatan ke pengamatan yang lain (Ghozali, 2016:134). Jika variance dari residual satu pengamatan ke pengamatan lain tetap, maka disebut Homoskedastisitas dan jika berbeda disebut Heteroskedastisitas.
Peneliti menggunakan metode uji Rank Spearman dalam pengujian ini. Jika variabel independen signifikan secara statistik mempengaruhi variabel dependen, maka ada indikasi terjadi heteroskedastisitas. Jika nilai sig. 2 tailed di atas tingkat kepercayaan 5\% atau $\alpha(0,05)$ maka tidak terjadi heteroskedastisitas.

d. Uji Autokorelasi

Uji autokorelasi bertujuan untuk menguji apakah model memiliki korelasi antara kesalahan pengganggu pada periode $t$ dengan kesalahan pengganggu pada periode t-1 (Ghozali, 2016:107). Model korelasi yang baik adalah regresi yang bebas dari autokorelasi. Peneliti menggunakan metode Runs untuk uji ini.

Pengambilan keputusan ada tidaknya korelasi:

(1) Jika Asymp. Sig > nilai $\alpha$ $(0,05)$, maka tidak terjadi autokorelasi.

(2) Jika Asymp. Sig < nilai $\alpha$ $(0,05)$, maka terjadi autokorelasi.

\section{Analisis Regresi Linier Berganda}

Analisis yang digunakan dalam penelitian ini dapat diuji dengan menggunakan analisis regresi berganda untuk menguji apakah terdapat keakuratan hubungan antara pengungkapan CSR (variabel dependen) yang dipengaruhi oleh variabel independen yaitu kinerja lingkungan, kepemilikan institusional, kepemilikan saham publik, leverage, ukuran perusahaan dan pertumbuhan perusahaan, diukur dengan rumus : 


\section{CSRD $=\beta_{0}+\beta_{1} \mathrm{KL}+\beta_{2} \mathrm{INST}+\beta_{3} \mathrm{KP}+\beta_{4} \mathrm{DER}+\beta_{5} \mathrm{SIZE}+\beta_{6} \mathrm{GROW}_{\mathrm{it}}+\varepsilon$}

Keterangan :

$\begin{array}{ll}\text { CSRD } & \text { : Pengungkapan CSR } \\ \beta_{0} & \text { : Konstanta } \\ \beta_{1}-\beta_{6} & : \text { Koefisien Regresi } \\ \text { KL } & \text { : Kinerja Lingkungan } \\ \text { INST } & : \text { Kepemilikan Institusional } \\ \text { KP } & : \text { Kepemilikan Saham Publik } \\ \text { DER } & : \text { Leverage } \\ \text { SIZE } & : \text { Ukuran Perusahaan } \\ \text { GROW } & : \text { Pertumbuhan Perusahaan } \\ \varepsilon & : \text { Error Term }\end{array}$

6. Uji Statistik

a. Uji Keberatian Model (Uji F)

Pengujian ini bertujuan untuk menunjukkan apakah semua variabel independen yang dimasukkan dalam model mempunyai pengaruh secara bersama-sama terhadap variabel dependen (Ghozali, 2016:96).

Dengan tingkat signifikansi sebesar 5 $\%$, maka kriteria pengujian adalah sebagai berikut:

1) Apabila nilai signifikansi $\mathrm{f}<0.05$, maka $\mathrm{H}_{0}$ ditolak, artinya terdapat pengaruh yang signifikan antara semua variabel independen terhadap variabel dependen.

2) Apabila nilai signifikansi $f>0.05$, maka $\mathrm{H}_{0}$ diterima, artinya semua variabel independen tidak berpengaruh terhadap variabel dependen.

b. Uji Signifikan Parameter Individual (Uji t)

Pengujian ini bertujuan untuk menunjukkan seberapa jauh pengaruh satu variabel penjelas atau independen secara individual dalam menerangkan variasi variabel dependen (Ghozali, 2016:97).

Dengan tingkat signifikansi $5 \%$, maka kriteria pengujian adalah sebagai berikut:

1) Apabila nilai signifikansi $t \leq 0.05$, maka Ho ditolak, artinya terdapat pengaruh yang signifikan antara satu variabel independen terhadap variabel dependen.

2) Apabila nilai signifikansi $t>0.05$, maka Ho diterima, artinya tidak ada pengaruh yang signifikan antara satu variabel independen terhadap variabel dependen.

c. Uji Koefisien Determinasi $\left(\mathrm{R}^{2}\right)$

Nilai $R^{2}$ digunakan untuk mengukur tingkat kemampuan model dalam menerangkan variasi variabel independen. Nilai koefisien determinasi adalah antara nol dan satu. Nilai $\mathrm{R}^{2}$ yang kecil berarti kemampuan variabel-variabel independen dalam menjelaskan variasi variabel dependen amat terbatas (Ghozali, 2016:95). Nilai yang mendekati satu berarti variabelvariabel independen memberikan hampir semua informasi yang dibutuhkan untuk memprediksi variasi variabel dependen.

\section{Hasil dan Pembahasan}

\section{Hasil Penelitian}

\section{Analisis Statistik Deskriptif}

Dapat dilihat pada tabel 2, hasilnya menunjukkan bahwa variabel pengungkapan tanggung jawab sosial (CSRD) memiliki nilai standar deviasi sebesar 0,11891 dengan 
nilai rata-rata sebesar 0,1584 yang berarti data CSRD tersebar. Nilai CSRD tertinggi yaitu sebesar 0,65 diperoleh dari PT. Timah (Persero) Tbk dan yang terendah adalah 0,04 yang diperoleh PT. Perdana Karya Perkasa Tbk.

Selain itu, variabel Kinerja Lingkungan memiliki nilai rata-rata 1,58 dan standar deviasi 1,65865 . Nilai terendah yaitu 0 diperoleh dari perusahaan yang tidak mengikuti program PROPER dan nilai maksimal 5 yang diperoleh PT Bukit Asam Tbk.

Variabel kepemilikan institusional memiliki nilai rata-rata 0,5901 dengan nilai standar deviasi sebesar 0,24654. Nilai terendah dari variabel ini adalah 0 yang didapat oleh PT Perdana Karya Perkasa Tbk. dan PT Bumi Teknokultura Unggul Tbk. sedangkan untuk nilai maksimal yaitu 0,97 diperoleh dari PT SMART Tbk.

Variabel kepemilikan saham publik memiliki nilai rata-rata 0,3482 dengan nilai standar deviasi sebesar 0,17422. Nilai terendah dari variabel ini adalah 0,03 yang diperoleh oleh PT Cita Mineral Investindo Tbk. sedangkan untuk nilai maksimal yaitu 0,87 diperoleh oleh PT Inti Agri Resources Tbk.

Variabel leverage yang diwakili oleh DER memiliki nilai rata-rata 1,9164 dengan nilai standar deviasi sebesar 4,17522. Nilai terendah dari variabel ini adalah 0,04 yang diperoleh oleh PT Inti Agri Resources Tbk. sedangkan untuk nilai maksimal yaitu 39,49 diperoleh oleh PT Central Proteinaprima Tbk.

Variabel ukuran perusahaan (size) memiliki nilai rata-rata 12,5595 dengan nilai standar deviasi sebesar 0,62637. Nilai terendah dari variabel ini adalah 11,20 yang diperoleh oleh PT Perdana Karya Perkasa Tbk. sedangkan untuk nilai maksimal yaitu
13,51 diperoleh oleh PT Salim Ivomas Pratama Tbk.

Variabel pertumbuhan penjualan memiliki nilai rata-rata 0,5656 dengan nilai standar deviasi sebesar 4,17871. Nilai terendah dari variabel ini adalah -0,96 yang diperoleh oleh PT Cita Mineral Investindo Tbk. pada tahun 2014 sedangkan untuk nilai maksimal yaitu 33,98 diperoleh oleh PT Cita Mineral Investindo Tbk. pada tahun 2016.

\section{Uji Kesamaan Koefisien}

Dari hasil uji pooling yang terdapat pada tabel 3, ditemukan bahwa semua variabel yang digunakan dalam penelitian ini dapat dipooling, karena semua variabel memiliki hasil signifikansi melebihi 0,05.

\section{Uji Asumsi Klasik}

\section{a. Uji Normalitas}

Berdasarkan uji normalitas yang telah dilakukan dengan menggunakan metode Kolmogorov-Smirnov Z (1-Sample K-S). Hasil data ditunjukan pada tabel 4, dimana nilai Asymp. Sig. 0,075>0,05 yang berarti data yang digunakan berdistribusi normal.

\section{b. Uji Multikolinearitas}

Berdasarkan hasil pengujian pada tabel 5, ditunjukkan hasil bahwa tidak terjadi multikolinearitas. Hal itu dapat dilihat dari nilai Tolerance $>0,1$ dan nilai VIF dari setiap variabel independen kurang dari 10.

\section{c. Uji Heteroskedastisitas}

Hasil yang didapat dari pengujian ini adalah tidak terjadi heteroskedastisitas. Hal ini dapat dibuktikan dengan dilihat nilai Sig. 2 tailed $>\alpha(0,05)$ pada kolom unstandardize residual (lihat tabel 6).

\section{d. Uji Autokorelasi}

Peneliti menggunakan metode Run Test untuk menguji apakah terdapat autokorelasi antara variabel independen. Hasil yang dapat dilihat di tabel 7 
menunjukan bahwa tidak terdapat autokorelasi antara variabel. Hasil output uji autokorelasi menunjukan nilai sig. $0,315>\alpha(0,05)$ yang berarti tidak terjadi autokorelasi antara variabel independen.
4. Hasil Analisis Regresi Linier Berganda

Berikut adalah hasil persamaan yang didapatkan dari hasil uji analisis regresi linier berganda sebagai berikut:

\section{CSRD $=-0,908+0,015 \mathrm{KL}+0,038$ INST + 0,188 KP - 0,004 DER + 0,077 SIZE - 0,002 GROW}

\section{Uji Statistik}

\section{a. Uji Keberartian Model (Uji F)}

Berdasarkan hasil pengujian yang dapat dilihat pada tabel 8 , diperoleh hasil nilai sig. $0,000<0,05$. Hal ini menunjukkan bahwa variabel independen secara bersama-sama berpengaruh terhadap variabel dependen.

\section{b. Uji Signifikan Parameter} Individual (uji t)

Berdasarkan hasil pengujian yang dapat dilihat pada tabel 9, diperoleh hasil bahwa kinerja lingkungan (KL) memiliki nilai sig sebesar $0,0145<$ 0,05 dengan nilai koefisien 0,212 yang berarti variabel kinerja lingkungan berpengaruh positif signifikan terhadap pengungkapan tanggung jawab sosial. Variabel kepemilikan institusional memiliki nilai sig sebesar $0,341>0,05$ dengan nilai keofisien 0,079 yang berarti variabel kepemilikan institusional tidak berpengaruh signifikan terhadap pengungkapan CSR.

Berdasarkan hasil pengujian untuk variabel kepemilikan saham publik memiliki nilai sig $0,058>0,05$. Hal itu berarti variabel kepemilikan publik tidak berpengaruh signifikan terhadap pengungkapan CSR.

Variabel leverage yang diukur dengan rasio DER menunjukkan hasil 0,077 > 0,05 . Hal tersebut berarti leverage tidak berpengaruh signifikan terhadap pengungkapan tanggung jawab sosial (CSR). Untuk variabel ukuran perusahaan dengan nilai sig $0,0005<$ 0,05 yang berarti variabel ukuran perusahaan berpengaruh positif secara signifikan terhadap pengungkapan tanggung jawab sosial. Variabel pertumbuhan perusahaan memiliki nilai sig 0,2305> 0,05 berarti tidak memiliki pengaruh yang signifikan antara pertumbuhan perusahaan dengan pengungkapan CSR.

\section{c. Koefisien Determinasi}

Berdasarkan hasil pengujian yang dapat dilihat pada tabel 10 , nilai yang diperoleh dari Adjusted $R$ Square sebesar 0,256 menunjukkan bahwa variabel pengungkapan tanggung jawab sosial dapat dijelaskan sebesar $25,6 \%$ melalui variabel kinerja lingkungan, kepemilikan institusional, kepemilikan publik, leverage, ukuran serta pertumbuhan perusahaan. Sedangkan $74,4 \%$ dijelaskan oleh variabel lainnya yang tidak dimasukkan dalam penelitian.

\section{Pembahasan}

1. Pengaruh Kinerja Lingkungan terhadap Pengungkapan CSR

Berdasarkan hasil pengujian yang telah dilakukan, kinerja lingkungan berpengaruh positif signifikan terhadap pengungkapan tanggung jawab sosial. Hasil penelitian ini sejalan dengan teori legitimasi karena hasil dari PROPER akan mempengaruhi penilaian masyarakat terhadap suatu perusahaan. Hasil penilaian PROPER yang ditentukan oleh KLH diumumkan secara annual melalui media online. Semakin taat suatu perusahaan dalam melakukan aktivitas sosial, tentu akan menghasilkan respon yang positif sehingga perusahaan tersebut akan 
mendapatkan kepercayaan atau legitimasi dari masyarakat.

Suatu perusahaan yang mengikuti program PROPER tentu akan mengungkapkan informasi mengenai CSR yang lebih luas. Hal itu disebabkan karena perusahaan akan lebih memperhatikan lingkungan dan membahasnya di laporan keuangan sebagai suatu keberhasilan dan kepedulian perusahaan terhadap masyarakat dan lingkungan sekitar.

Dengan adanya pengungkapan sosial perusahaan yang merupakan bentuk tanggung jawab perusahaan terhadap masyarakat, maka akan menciptakan kepercayaan masyarakat terhadap perusahaan. Hal ini dikarenakan perusahaan sudah mampu menjaga kelestarian lingkungan dan mampu beroperasi dengan baik tanpa adanya pihak-pihak yang dirugikan, sehingga sesuai dengan teori legitimasi yang menyatakan bahwa jika perusahaan melaksanakan kegiatan operasinya dengan baik maka masyarakat juga akan merespon positif terhadap keberlangsungan hidup perusahaan. Hasil penelitian ini sejalan dengan penelitian yang dilakukan oleh Permana dan Raharja (2012:7) yang menyatakan hasil bahwa kinerja lingkungan berpengaruh terhadap pengungkapan tanggung jawab sosial perusahaan.

\section{Pengaruh Kepemilikan Institusional terhadap Pengungkapan CSR}

Berdasarkan hasil pengujian di atas ditemukan variabel kepemilikan institusional tidak berpengaruh secara signifikan terhadap pengungkapan CSR. Hasil temuan tersebut sejalan dengan teori stakeholder yang menyatakan bahwa perusahaan bukanlah entitas yang hanya beroperasi untuk kepentingannya sendiri namun harus memberikan manfaat bagi stakeholders. Hal itu berarti besarnya persentase kepemilikan institusi tidak mempengaruhi luas pengungkapan CSR.

Jika dilihat dari rasio pengungkapan CSR yang dilakukan perusahaan dibandingkan dengan rasio kepemilikan saham institusi suatu perusahaan dapat ditunjukkan bahwa semakin tinggi kepemilikan institusi tidak mendorong pengungkapan CSR yang semakin luas pula dan begitupun sebaliknya sehingga kepemilikan institusi tidak memiliki pengaruh signifikan terhadap pengungkapan CSR. Hal ini sejalan dengan penelitian yang dilakukan oleh Bangun, dkk (2012:730) yang menemukan hasil bahwa kepemilikan institusi tidak berpengaruh signifikan terhadap pengungkapan tanggung jawab sosial.

\section{Pengaruh Kepemilikan Publik terhadap Pengungkapan CSR}

Berdasarkan pengujian yang dilakukan antara variabel kepemilikan publik dengan pengungkapan tanggung jawab sosial didapatkan hasil bahwa kepemilikan publik tidak berpengaruh terhadap pengungkapan tanggung jawab sosial. Hal tersebut mungkin menunjukkan bahwa publik sebagai pemilik perusahaan merupakan bagian yang terpisah-pisah, bukan kepemilikan bersama, sehingga kekuatan yang dimiliki untuk mempengaruhi manajemen sangat rendah. Oleh karena itu, perannya tidak cukup kuat untuk mendorong manajemen dalam mengungkapkan informasi CSR sebanyakbanyaknya.

Jika dilihat dari rasio pengungkapan CSR yang dilakukan perusahaan dibandingkan dengan rasio kepemilikan saham publik suatu perusahaan dapat ditunjukkan bahwa semakin tinggi kepemilikan institusi tidak mendorong pengungkapan CSR yang semakin luas pula dan begitupun sebaliknya sehingga kepemilikan institusi tidak memiliki pengaruh signifikan terhadap pengungkapan CSR. Hasil penelitian ini sejalan dengan penelitian yang dilakukan 
oleh Evandini dan Darsono (2014:8) bahwa kepemilikan publik tidak berpengaruh terhadap pengungkapan CSR.

\section{Pengaruh Leverage terhadap Pengungkapan CSR}

Hasil pengujian yang telah dilakukan menunjukkan nilai sig $0,154>0,05$ yang berarti leverage tidak memiliki pengaruh terhadap pengungkapan tanggung jawab sosial. Hal ini menunjukkan bahwa tinggi rendahnya tingkat leverage tidak mempengaruhi pengungkapan CSR. Hasil penelitian ini juga bertentangan dengan teori keagenan yang memprediksi bahwa perusahaan dengan rasio leverage yang tinggi akan mengungkapkan informasi lebih banyak.

Terdapat kemungkinan bahwa variabel leverage ini melibatkan pihak ketiga sehingga kurang memberikan dorongan bagi perusahaan untuk mengungkapkan informasi mengenai tanggung jawab sosial. Dana yang tersedia atas pinjaman/hutang dari pihak ketiga bisa saja digunakan untuk memperluas pasar, membayar biaya operasional dan lainnya. Besar atau kecilnya tingkat leverage pada perusahaan tidak menjamin bahwa mereka akan melakukan kegiatan CSR. Di dalam penelitian ini, perusahaan tetap melakukan dan mengungkapkan aktivitas CSR. Meskipun perusahaan tersebut memiliki nilai leverage yang tinggi, hal itu tidak mempengaruhi mereka dalam melaksanakan program CSR. Hasil penelitian ini sejalan dengan penelitian yang dilakukan oleh Paramitha (2016:14) yang menyatakan bahwa variabel leverage tidak berpengaruh terhadap pengungkapan CSR.

\section{Pengaruh Ukuran Perusahaan terhadap Pengungkapan CSR}

Berdasarkan pengujian yang telah dilakukan, terdapat pengaruh antara ukuran perusahaan dengan pengungkapan tanggung jawab sosial. Temuan ini mengimplikasikan bahwa besar kecilnya ukuran perusahaan akan memengaruhi keluasan pengungkapan tanggung jawab sosial. Hasil ini sejalan dengan teori agensi dimana semakin besar ukuran perusahaan maka semakin besar pula biaya keagenan yang harus dianggarkan. Untuk mengurangi biaya keagenan, perusahaan wajib untuk mengungkapkan informasi secara lengkap dan detail.

Perusahaan dengan ukuran yang lebih besar dituntut untuk menghasilkan kinerja/performance yang lebih tinggi. Salah satu cara memperlihatkan performance yang baik adalah dengan memperhatikan kondisi lingkungan sosial, melakukan aktivitas CSR, dan mengungkapkannya di dalam laporan tahunan perusahaan. Hasil penelitian tersebut sejalan dengan penelitian yang dilakukan oleh Evandini dan Darsono (2014:8) yang menunjukkan hasil serupa yaitu variabel SIZE berpengaruh signifikan terhadap CSR.

\section{Pengaruh Pertumbuhan Perusahaan terhadap Pengungkapan CSR}

Berdasarkan hasil penelitian yang dilakukan, tidak ditemukan adanya pengaruh yang signifikan antara pertumbuhan perusahaan dengan pengungkapan tanggung jawab sosial. Suatu perusahaan yang melaksanakan pengungkapan tanggung jawab sosial secara luas tentu akan berdampak positif bagi perusahaan seiring dengan meningkatnya kepercayaan masyarakat yang diharapkan akan berdampak bagi peningkatan penjualan. Namun, terkadang pengungkapan CSR yang dilakukan perusahaan hanya sebagai media promosi untuk menarik minat para stakeholder dan masyarakat sehingga hanya sekadar mencantumkan tetapi tidak memberikan informasi yang jelas. Selain itu, para investor biasanya hanya mementingkan laba yang merupakan 
kinerja jangka pendek perusahaan dan tidak begitu mementingkan pengungkapan tanggung jawab sosial yang dilakukan oleh perusahaan sehingga pertumbuhan perusahaan tidak terbukti berpengaruh terhadap pengungkapan CSR.

Hasil penelitian ini sejalan dengan penelitian yang dilakukan oleh Lomboan, dkk. (2016:29) yang menemukan bahwa variabel growth tidak berpengaruh signifikan terhadap pengungkapan tanggung jawab sosial perusahaan. Hal tersebut didasari oleh investor lebih tertarik dengan kinerja keuangan perusahaan jangka pendek dengan beorientasi pada keuntungan yang diperoleh pada tahun berjalan.

\section{Simpulan dan Saran}

Berdasarkan pembahasan sebelumnya, dapat disimpulkan bahwa terdapat cukup bukti antara variabel kinerja lingkungan dan ukuran perusahaan berpengaruh terhadap pengungkapan CSR, sedangkan variabel kepemilikan institusional, kepemilikan publik, leverage dan pertumbuhan perusahaan tidak terbukti memliki pengaruh terhadap pengungkapan CSR.

Beberapa saran yang dapat diberikan bagi peneliti selanjutnya. Apabila ingin meneliti topik yang sama, disarankan untuk menambah jumlah sampel dan periode penelitian sehingga dapat diperoleh hasil yang lebih baik. Kemudian, peneliti selanjutnya dapat melakukan pengamatan item-item CSR secara teliti. Serta menggunakan pengukuran lain selain yang digunakan oleh peneliti untuk melihat apakah terjadi perbedaan hasil apabila digunakan rasio yang berbeda

\section{Daftar Pustaka}

Anggraini, R. R. 2006. Pengungkapan Informasi Sosial dan Faktor-Faktor yang Mempengaruhi Pengungkapan
Informasi Sosial dalam Laporan Keuangan Tahunan (Studi Empiris pada Perusahaan-Perusahaan yang Terdaftar Bursa Efek Jakarta. Simposium Nasional Akuntansi 9 Padang, 1-21.

Bangun, N., Octavia, J., \& Tarigan, K. B. 2012. Pengaruh Kepemilikan Manajerial, Kepemilikan Institusional, dan Profitabilitas Terhadap Pengungkapan Corporate Social Responsibility pada Perusahaan yang Terdaftar di BEI. Jurnal Akuntansi, Volume 12, Nomor 2, 717-738.

Evandini, C., \& Darsono. 2014. Faktor-Faktor yang Berpengaruh Terhadap Pengungkapan Tanggung Jawab Sosial Perusahaan pada Perusahaan Manufaktur yang Terdaftar di BEI. Diponegoro Journal of Accounting Volume 3, Nomor 3, 1-11.

Fauzan. 2014. Corporate Social Responsibility dan Etika Bisnis (Perspektif Etika Moral Immanuel Kant). MODERNISASI, Volume 7, Nomor 2, 115-133.

Ghozali, I. 2016. Aplikasi Analisis Multivariete dengan Program IBM SPSS 23. Semarang: Badan Penerbit Universitas Diponegoro.

Ghozali, I., \& Chariri, A. 2007. Teori Akuntansi. Semarang: Badan Penerbit Universitas Diponegoro.

Hadi, N. 2011. Corporate Social Responsibility. Yogyakarta: Graha Ilmu.

Jensen, M. C., \& Meckling, W. H. 1976. Theory of The Firm: Managerial Behavior, Agency Costs and Ownership Structure. Journal of Financial Economics 3, 305-360. 
Kamil, A., \& Herusetya, A. 2012. Pengaruh Karakteristik Perusahaan Terhadap Luas Pengungkapan Kegiatan Corporate Social Responsibility. Media Riset Akuntansi Vol. 2, 1-17.

Karima, N. 2014. Pengaruh Kepemilikan Manajerial, Kepemilikan Institusional, dan Kepemilikan Asing Terhadap Pengungkapan Tanggung Jawab Sosial Perusahaan. Widya Warta No. 02, 219-230.

Lomboan, A. M., Sondakh, J. J., \& Pontoh, W. 2016. Pengaruh Profitabiliitas, Leverage, Growth, Size Terhadap Harga Saham dengan Pengungkapan Tanggung Jawab Sosial Sebagai Variabel Intervening pada Perusahaan yang Terdaftar di Bursa Efek Indonesia. Jurnal Riset Akuntansi dan Auditing Volume 7, Nomor 1, 24-42.

Munsaidah, S., Andini, R., \& Supriyanto, A. 2016. Analisis Pengaruh Firm Size, Age, Profitabilitas, Leverage, dan Growth Perusahaan Terhadap Corporate Social Responsibility. Journal Of Accounting, Volume 2, Nomor 2.

Oktalia, D. 2014. Pengaruh Kinerja Lingkungan dan Profitabilitas Terhadap Corporate Social Responsibility Disclosure Dalam Laporan Tahunan Perusahaan. Jurnal Akuntansi.

Oktariani, W. N., \& Mimba, N. P. 2014. Pengaruh Karakteristik Perusahaan dan Tanggung Jawab Lingkungan pada Pengungkapan Tanggung Jawab Sosial Perusahaan. E-Journal Akuntansi Universitas Udayana 6.3, 402-418.

Paramitha, N. A. 2016. Pengaruh Karakteristik Perusahaan, Komisaris, Profitabilitas, dan Leverage Terhadap Pengungkapan Corporate Social Responsibility. Jurnal Ilmu dan Riset
Manajemen, Volume 5, Nomor 10, 116.

Permana, V. A., \& Raharja, R. (2012). Pengaruh Kinerja Lingkungan dan Karakteristik Perusahaan terhadap Corporate Social Responsibiity (CSR) Disclosure (Studi Empiris pada Perusahaan Manufaktur yang Terdaftar di BEI) . Diponegoro Journal of Accounting, 1-12.

HYPERLINK "http://proper.menlhk.go.id/" proper.menlhk.go.id/

Purwanto, A. 2011. Pengaruh Tipe Industri, Ukuran Perusahaan, Profitabilitas Terhadap Corporate Sosial Responsibility. Jurnal Akuntansi \& Auditing, Volume 8, Nomor 1, 12-29.

Rahayu, P. 2015. Skripsi: Pengaruh Kepemilikan Saham Publik, Profitabilitas dan Pengungkapan Media Terhadap Pengungkapan Tanggung Jawab Sosial pada Perusahaan Property dan Real Estate yang Terdaftar di Bursa Efek Indonesia Tahun 2011-2013. Universitas Negeri Semarang.

Rakhiemah, A. N., \& Agustia, D. 2009. Pengaruh Kinerja Lingkungan terhadap Corporate Sosial Responsibility (CSR) Disclosure dan Kinerja Finansial Perusahaan Manufaktur yang Terdaftar di Bursa Efek Indonesia. Simposium Nasional Akuntansi XII.

Rochayatun, S. 2016. Faktor-Faktor yang mempengaruhi Corporate Social Responsibility Disclosure. Jurnal Penelitian Ilmu Ekonomi WIGA, Volume 6, Nomor 1, 63-79.

Sartono, A. 2010. Manajemen Keuangan Teori dan Aplikasi. Edisi Keempat. Yogyakarta: BPFE. 
Suchman, M. C. 1995. Managing Legitimacy: Strategic and Institutional Approaches. The Academy of Management Review, Vol. 20, No. 3, 571-610.

Sukanto, E., \& Widaryanti. 2014. Pengaruh Pengungkapan Corporate Social Responsibility Terhadap Stock Return
Pada Perusahaan yang Berkaitan dengan Lingkungan yang Listing di Bursa Efek Indonesia. Fokus Ekonomi, Vol. 9, No. 2, 34-42.

\section{Lampiran}

Teknik Pengambilan Sampel

Tabel 1

Proses Pengambilan Sampel

\begin{tabular}{lc}
\hline Keterangan & Jumlah \\
Entitas \\
\hline Perusahaan Pertanian dan Pertambangan terdaftar di BEI s/d 2013 \\
Perusahaan yang tidak menyajikan laporan tahunan secara lengkap & 59 \\
Perusahaan yang delisting & $(6)$ \\
Perusahaan yang menggunakan mata uang selain Rupiah & $(3)$ \\
Jumlah perusahaan yang listing yang menjadi sampel & $25)$ \\
Total sampel penelitian (4 tahun) & 100 \\
\hline
\end{tabular}

\section{Hasil Pengujian SPSS}

Statistik Deskriptif

Tabel 2

Descriptive Statistics

\begin{tabular}{|l|c|c|c|c|c|}
\hline & $\mathrm{N}$ & $\begin{array}{c}\text { Minimu } \\
\mathrm{m}\end{array}$ & $\begin{array}{c}\text { Maximu } \\
\mathrm{m}\end{array}$ & Mean & $\begin{array}{c}\text { Std. } \\
\text { Deviatio } \\
\mathrm{n}\end{array}$ \\
\hline CSRD & 100 &, 04 &, 65 &, 1584 &, 11891 \\
$\mathrm{KL}$ & 100 &, 00 & 5,00 & 1,5800 & 1,65865 \\
$\mathrm{INST}$ & 100 &, 00 &, 97 &, 5901 &, 24654 \\
$\mathrm{KP}$ & 100 &, 03 &, 87 &, 3482 &, 17422 \\
$\mathrm{DER}$ & 100 &, 04 & 39,49 & 1,9164 & 4,17522 \\
SIZE & 100 & 11,20 & 13,51 & 12,559 &, 62637 \\
GROW & 100 &,- 96 & 33,98 &, 5656 & 4,17871 \\
Valid N & 100 & & & & \\
(listwise) & & & & & \\
\hline
\end{tabular}

Sumber : Output SPSS 20 


\section{Uji Kesamaan Koefisien}

Tabel 3

Hasil Uji Pooling

\begin{tabular}{|c|c|c|c|c|c|c|}
\hline \multirow{2}{*}{\multicolumn{2}{|c|}{ Model }} & \multicolumn{2}{|c|}{ Unstandardized Coefficients } & \multirow{2}{*}{$\begin{array}{l}\text { Standardized } \\
\text { Coefficien } \\
\text { ts } \\
\text { Beta }\end{array}$} & \multirow[t]{2}{*}{$\mathrm{t}$} & \multirow[t]{2}{*}{ Sig. } \\
\hline & & $\mathrm{B}$ & Std. Error & & & \\
\hline \multirow{28}{*}{1} & (Constant) &,- 618 & ,681 & &,- 908 & ,367 \\
\hline & KL & ,037 &, 020 & ,509 & 1,880 & ,064 \\
\hline & INST & ,048 & ,207 &, 100 & ,232 & ,817 \\
\hline & $\mathrm{KP}$ &, 146 & ,233 & ,213 & ,626 &, 533 \\
\hline & DER &,- 002 & ,003 &,- 085 &,- 796 & ,429 \\
\hline & SIZE &, 052 &, 060 &, 275 & ,867 & ,389 \\
\hline & GROW &,- 001 & ,003 &,- 030 &,- 248 & 805 \\
\hline & DT1 & ,392 & ,948 & 1,436 &, 414 & 680 \\
\hline & DT2 & ,402 & ,995 & 1,470 & ,403 & ,688 \\
\hline & DT3 & ,261 & ,972 & ,957 &, 269 & ,789 \\
\hline & DT1_KL &,- 009 & ,027 &,- 073 &,- 321 & ,749 \\
\hline & DT1_INST & ,018 & ,294 & ,043 & ,062 & ,951 \\
\hline & DT1_KP & ,079 & ,329 & ,119 &, 240 & ,811 \\
\hline & DT1_DER &,- 006 & ,020 &,- 046 &,- 298 & ,767 \\
\hline & DT1_SIZE &,- 033 & ,086 & $-1,512$ &,- 386 & ,701 \\
\hline & $\begin{array}{l}\text { DT1_GRO } \\
\text { W }\end{array}$ & ,018 & ,092 & ,020 & ,192 & ,848 \\
\hline & DT2_KL & ,001 & ,030 & ,004 & ,017 & ,987 \\
\hline & DT2_INST &, 031 & ,294 &, 075 & ,106 & ,916 \\
\hline & DT2_KP &,- 035 & ,381 &,- 049 &,- 093 & ,926 \\
\hline & DT2_DER &,- 001 & ,017 &,- 013 &,- 087 & ,931 \\
\hline & DT2_SIZE &,- 032 & ,087 & $-1,452$ &,- 363 & ,718 \\
\hline & $\begin{array}{c}\text { DT2_GRO } \\
\text { W }\end{array}$ &,- 054 & ,063 &,- 096 &,- 857 & ,394 \\
\hline & DT3_KL &,- 006 & ,027 &,- 055 &,- 239 & ,812 \\
\hline & DT3_INST & ,095 & ,303 & ,231 & ,312 & ,756 \\
\hline & DT3_KP & , 128 & ,375 & , 174 &, 341 & ,734 \\
\hline & DT3_DER &, 002 & ,017 & ,017 &, 101 & ,920 \\
\hline & DT3_SIZE &,- 029 & ,087 & $-1,335$ &,- 332 & ,741 \\
\hline & $\begin{array}{c}\text { DT3_GRO } \\
\text { W }\end{array}$ &,- 001 & ,007 &,- 014 &,- 103 & ,918 \\
\hline
\end{tabular}

Sumber : Output SPSS 20 
Uji Asumsi Klasik

\section{Hasil Uji Normalitas \\ Tabel 4 \\ Uji Normalitas}

\begin{tabular}{|ll|l|}
\hline & & $\begin{array}{c}\text { Unstandardiz } \\
\text { ed } \\
\text { Residual }\end{array}$ \\
\hline $\mathrm{N}$ & Mean & 100 \\
& & $0 \mathrm{E}-7$ \\
Normal Parametersa,b & Std. &, 09939597 \\
& Deviation &, 128 \\
Most Extreme & Absolute &, 128 \\
Differences & Positive &,- 097 \\
Kolmogorov-Smirnov Z & Negative & 1,281 \\
Asymp. Sig. (2-tailed) & &, 075 \\
\hline
\end{tabular}

Sumber : Output SPSS 20

Hasil Uji Multikolinearitas

Tabel 5

Uji Multikolinearitas

\begin{tabular}{|c|c|c|c|c|c|c|c|c|}
\hline \multirow{2}{*}{\multicolumn{2}{|c|}{ Model }} & \multicolumn{2}{|c|}{$\begin{array}{r}\text { Unstandardized } \\
\text { Coefficients }\end{array}$} & \multirow{2}{*}{$\begin{array}{c}\begin{array}{c}\text { Standardiz } \\
\text { ed } \\
\text { Coeffici } \\
\text { ents }\end{array} \\
\text { Beta }\end{array}$} & \multirow[t]{2}{*}{$\mathrm{t}$} & \multirow[t]{2}{*}{ Sig. } & \multicolumn{2}{|c|}{$\begin{array}{r}\text { Collinearity } \\
\text { Statistics }\end{array}$} \\
\hline & & B & Std. Error & & & & $\begin{array}{c}\text { Toleran } \\
\text { ce }\end{array}$ & VIF \\
\hline \multirow{7}{*}{1} & $\begin{array}{c}\text { (Const } \\
\text { ant } \\
)\end{array}$ &,- 908 & ,237 & & $-3,834$ & ,000 & & \\
\hline & $\mathrm{KL}$ & ,015 & ,007 & ,212 & 2,216 & ,029 & ,820 & 1,220 \\
\hline & INST & ,038 & ,092 & ,079 & ,412 & ,682 & ,206 & 4,843 \\
\hline & $\mathrm{KP}$ &, 188 & , 118 &, 275 & 1,588 & ,116 &, 251 & 3,987 \\
\hline & DER &,- 004 & ,003 &,- 130 & $-1,437$ & ,154 & ,923 & 1,083 \\
\hline & SIZE & ,077 & ,021 &, 404 & 3,576 & ,001 & ,589 & 1,696 \\
\hline & $\begin{array}{r}\text { GRO } \\
\text { W }\end{array}$ &,- 002 & ,003 &,- 065 &,- 740 & ,461 & ,960 & 1,042 \\
\hline
\end{tabular}

Sumber : Output SPSS 20 
Hasil Uji Heterokedastisitas

Tabel 6

Uji Heterokedastisitas

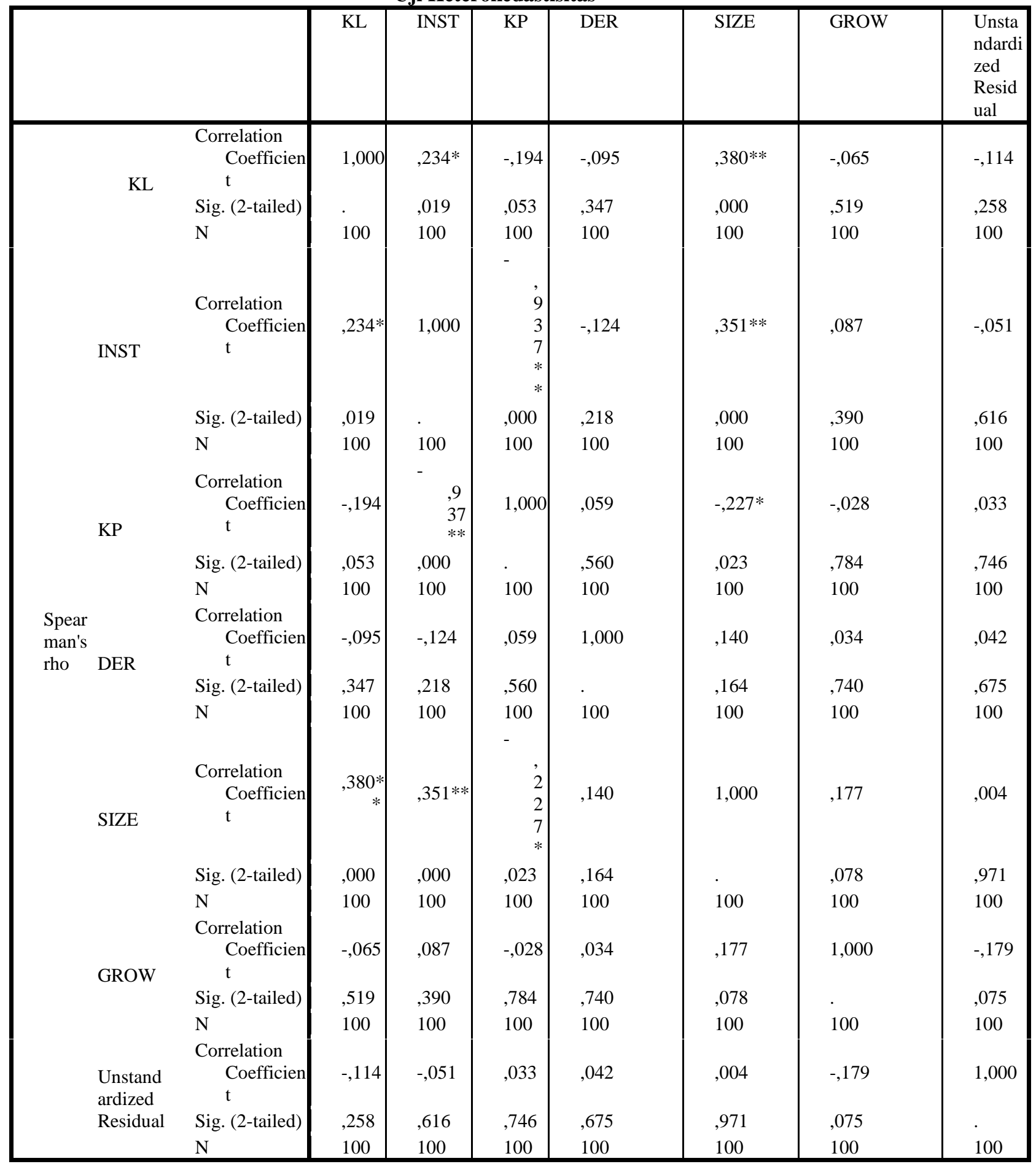

Sumber : Output SPSS 20 


\section{Hasil Uji Autokorelasi}

Tabel 7

Uji Autokorelasi

\begin{tabular}{|l|l|}
\hline & RES3 \\
\hline Test Valuea &, 05 \\
Cases < Test Value & 50 \\
Cases >= Test Value & 50 \\
Total Cases & 100 \\
Number of Runs & 46 \\
Z & $-1,005$ \\
Asymp. Sig. (2- &, 315 \\
\hline tailed) & \\
\hline
\end{tabular}

Sumber : Output SPSS 20

\section{Uji Statistik}

\section{Hasil Uji F}

Tabel 8

Uji F

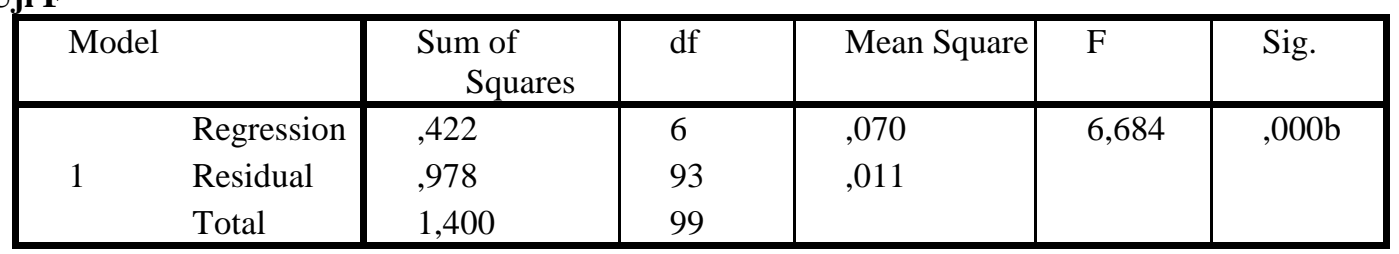

Sumber : Output SPSS 20

\section{Hasil Uji t}

Tabel 9

Uji $t$

Coefficientsa

\begin{tabular}{|c|c|c|c|c|c|c|}
\hline \multirow{2}{*}{\multicolumn{2}{|c|}{ Model }} & \multicolumn{2}{|c|}{ Unstandardized Coefficients } & \multirow{2}{*}{$\begin{array}{l}\text { Standardized } \\
\text { Coefficien } \\
\text { ts } \\
\text { Beta }\end{array}$} & \multirow[t]{2}{*}{$\mathrm{t}$} & \multirow[t]{2}{*}{ Sig. } \\
\hline & & $\mathrm{B}$ & Std. Error & & & \\
\hline \multirow{7}{*}{1} & (Constant) &,- 908 & ,237 & & $-3,834$ &, 000 \\
\hline & $\mathrm{KL}$ &, 015 & ,007 & ,212 & 2,216 & 029 \\
\hline & INST & ,038 & ,092 & 079 & ,412 & ,682 \\
\hline & $\mathrm{KP}$ &, 188 &, 118 & 275 & 1,588 &, 116 \\
\hline & DER &,- 004 & ,003 &,- 130 & $-1,437$ & , 154 \\
\hline & SIZE & 077 & 021 & ,404 & 3,576 & 001 \\
\hline & GROW &,- 002 & ,003 &,- 065 &,- 740 & ,461 \\
\hline
\end{tabular}

Sumber : Output SPSS 20 
Hasil Uji Koefisien Determinasi

Tabel 10

Uji Koefisien Determinasi

\begin{tabular}{|c|c|c|c|c|}
\hline $\begin{array}{c}\text { Mode } \\
1\end{array}$ & $\mathrm{R}$ & $\mathrm{R}$ Square & $\begin{array}{c}\text { Adjusted } \mathrm{R} \\
\text { Square }\end{array}$ & $\begin{array}{c}\text { Std. Error of } \\
\text { the } \\
\text { Estimate }\end{array}$ \\
\hline 1 &, $549 \mathrm{a}$ &, 301 &, 256 &, 10255 \\
\hline
\end{tabular}

Sumber : Output SPSS 20 